\title{
Analysis of Some Factors Affecting Business Performance From Non-Financial Aspects at Enterprises in Nam Dinh Province
}

\author{
Thi Lan Anh, Nguyen \\ Faculty of Accounting and Auditting \\ Hanoi University of Industry \\ nguyenthilananh@haui.edu.vn \\ Thanh Hang, Truong \\ Faculty of Accounting and Auditting \\ Hanoi University of Industry \\ truongthanhhang@haui.edu.vn
}

\author{
Van Linh, Nguyen \\ Department of Accounting \& Finance \\ Hanoi University of Industry \\ nguyenvanlinh@haui.edu.vn \\ Thi Thuy, Bui \\ Academy of Banking, Vietnam \\ thuybt@hvnh.edu.vn
}

\begin{abstract}
Business performance of enterprises is evaluated by many different models, most of which use financial measures. However, traditional financial measures cannot provide information for strategy development because they skip customer satisfaction and quality of products and services... Therefore, non-financial measures for business performance is gaining a special advantage, in which the Balanced Scorecard model (BSC) with customers, internal processes and development training as non-financial measures has been widely recognized by many companies and highly regarded by many researchers for its role in the strategic management of enterprises. This article aims to examine the factors affecting business performance from non-financial aspects (customers, internal processes and development training) of enterprises in Nam Dinh province. The study used the quantitative research method and SPSS 26 data processing software, and is based on the estimated linear regression model with $\mathbf{5 2 0}$ feedbacks from enterprises in various fields of operation in Nam Dinh province in 2020. The research results show that the factors affecting business performance in terms of non-financial aspects are ranked in the following order: (1) Use of resources, (2) Market orientation, (3) Information technology (IT), (4) Local policies, (5) Capital accessibility and usage, and (6) State policies. On that basis, the article proposes some suitable solutions for managers to improve the business performance of enterprises in Nam Dinh province.
\end{abstract}

Index Terms-Business performance, influencing factors, enterprise, financial, non-financial, Nam Dinh province.

\section{INTRODUCTION}

$I^{N}$ $\mathrm{N}$ AN increasingly fierce competitive environment, business performance evaluation becomes a basis for making management decisions. Historically, many different model for business performance evaluation have been developed that use both financial and non-financial measures such as the Balanced Scorecard BSC in [1]. The SMART pyramid model of [2] includes strategic goals and dimension of operations through 4 levels of structure appropriate for both financial and non-financial aspects of the organization. This model creates a management control system with business performance evaluation criteria at all management levels, but lacks the integration of continuous improvement. The Process Management Matrix (PMM) developed by [3] integrates financial and non-financial aspects, internal aspects and external aspects, in which internal aspects include finance (price competition criteria, relevant marketing criteria, cost, added productivity value, warranty costs) and non-financial aspects include product reliability criteria, number of customer complaints, market share, on-time delivery, number of new products. The model of business performance of Cambridge [4] integrates internal, external, financial and non-financial factors with the strategic system in the organization's operations. Most models are based on financial and non-financial measures because the success of an enterprise is a multidimensional concept that depends on the design, production, marketing and distribution of products or services and usually in a complex and dynamic environment. Thus, focusing solely on financial measures may lead to failure to adapt to the new business environment, as pointed out by [5]. Non-financial measures also provide feedback on the company's activities that can directly and indirectly affect the business performance. This study examines the measurement of business performance by non-financial criteria, using customer, internal process, training and development ([1]) for a comprehensive and flexible evaluation across all aspects of business performance of the organization.

In fact, there are many factors that affect the business performance of enterprises. It is extremely necessary for businesses to find out which are affecting factors and to what extent the factors affect the business performance of enterprises as the basis for improvement. According to statistics in 2020, in Nam Dinh province, there are 6,061 enterprises operating in different fields; they are located in nine districts and one city. These enterprises contribute significantly to economic growth and job creation. However, they achieve low profit with the return on sales ratio (ROS) of only $0.15 \%$, lower than the national average ratio of $0.20 \%$ (Nam Dinh Statistical Yearbook, 2020). Therefore, the analysis of factors affecting business performance in terms of non-financial aspects is necessary for enterprises in Nam Dinh province.

\section{Literature Review}

There have been many studies on the factors affecting business performance:

Group of factors belonging to characteristics of enterprises: (1) Size of enterprise: In many studies, size has a positive influence on the business performance of enter- 
prises. Size of enterprise is measured by number of employees, capital, assets, revenue. Aaccording to [6], [7], the larger the size of the enterprise, the higher the efficiency. (2) Age of enterprise: according to studies by [8], [9] the age of an enterprises is a factor that affects the business existence and development [10] agrees that the longer an enterprise has been in operation, the higher its operational efficiency will be because it has built a reputation and brand name in the market. (3) Type of enterprise: the variable of enterprise type is included in the study of business performance. The study results show that ROS has a positive correlation with the type of enterprises, according to [11], and [12]. (4) Business sector: In the study of [13], the factor of business sector has the strongest impact on business performance of enterprises in a number of fields such as real estate, educational services, petroleum, tobacco.

Group of factors on business leadership: According to the study by [9], the education level and competence of the director have a positive influence on the business operation of the enterprise. When the director is capable, well-trained, experienced and qualified, it will help the enterprise develop. [11] also points out that enterprises in which the director has a university degree or higher has a higher return on assets ratio (ROA) than the rest. Regarding gender, if the leader is a man, it will contribute to the increase of business activities of enterprises due to the dynamism and decisiveness of men in finding, planning and choosing business options as well as in social relationships that bring benefits to enterprises, as in studies by [14], [15], [12]. Some studies also show that managers' experience (number of years in management) affects ROA. The study [11] concludes that ROA of enterprises increased by $1.19 \%$ when the experience of the director of the enterprise increased by 1 year.

The factor of capital accessibility and usage: According to [16], the factor of capital has a positive influence on the business performance of enterprises. [11] believes that the ROA of enterprises will decrease by $5.95 \%$ when the total charter capital of enterprises increases to 1 billion dong, which has a negative correlation with business performance. The lack of collateral is the reason why enterprises cannot borrow or can only borrow little credit from commercial banks, according to [17]. The factor of resources of the enterprise: The resource-based view (RBV) holds that firms have resources which are unique, rare, valuable, and non-replaceable, allowing them to achieve a sustainable competitive advantage, according to [18]. [19] find an unrelated association between employee satisfaction and financial performance, mediated by customer satisfaction.

Human Resource Management (HRM) enables the creation of a workforce that helps an organization achieve its goals and mission. [16] suggests that the factors belonging to the internal capacity of enterprises, including market information, marketing, labor qualifications, equipment, affect business operation of enterprises.

The IT factor: Information and technology increases efficiency and business performance through ROA and return on investment (ROI), according to [20], [21]. At the same time, [22] states that investment in information technology contributes significantly to enterprises' growth and business performance. According to [23], investment in IT helps or- ganizations modernize business operations. [21] points out information technology has a positive impact on financial performance.

The factor of local policies: according to [16], local policies have a positive influence on the business activities of enterprises. The study of [24] also suggests that local policies have a great influence on the business performance of enterprises

The factor of state policy: according to [24], the government's macro policies affect business performance, which is similar to the viewpoint of [30], [11]. Besides, [10] once again verifies the extent to which access to government support policies affects the business performance of enterprises.

From the research gaps that have been drawn after the literature review, specific research directions are determined as follows: the team of authors will study the influence of internal and external factors on business performance in enterprises in Nam Dinh province, in which priority is given to internal factors. Business performance of enterprises will be measured from non-financial aspects (measured by the indicators of customers, internal processes and training and development). This study uses a combination of qualitative and quantitative research methods.

\section{Proposed Research Model and Method}

\section{A. Proposed model}

Based on the research overview, the group proposes a specific research model as follows: Figure 1. Research model

\subsection{Research method}

To verify the research model and hypotheses, the authors designed a questionnaire. After filtering the observed vari-

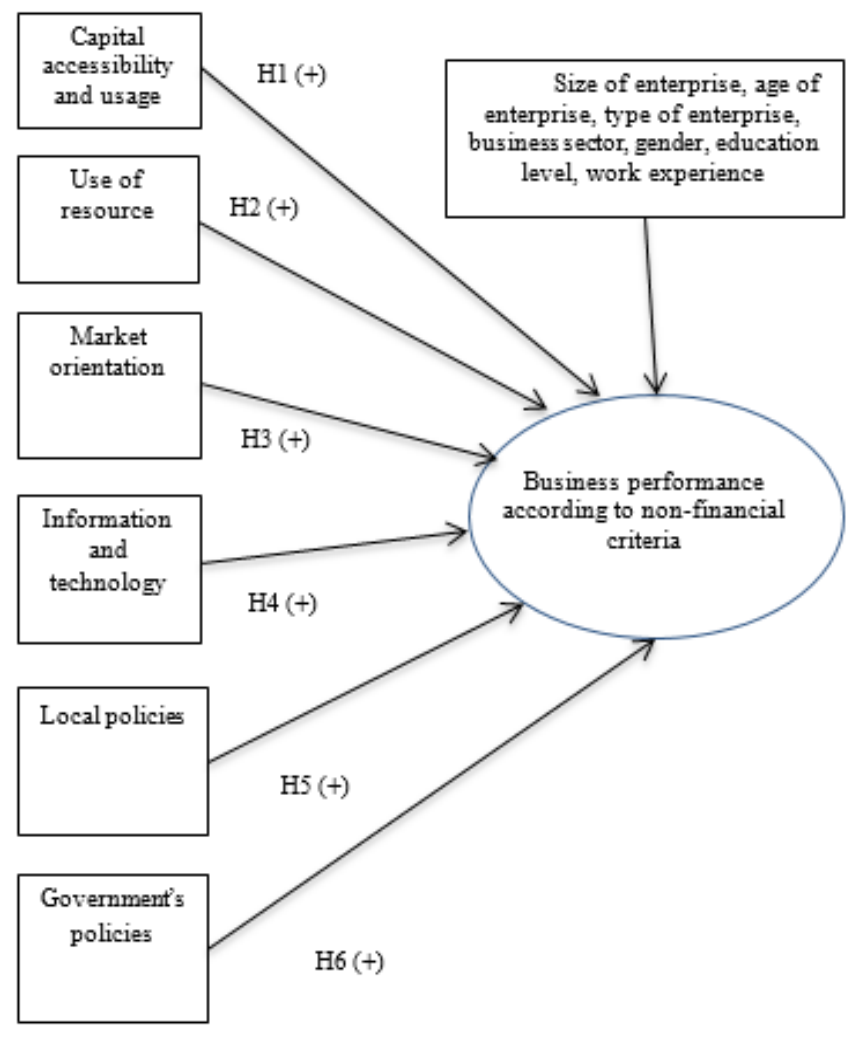

Fig. 1 Research model 
ables in previous studies to match the context of enterprises in Nam Dinh province, the authors put together a questionnaire consisting of 40 observed variables for independent variables and 24 observations for the dependent variable, measured by a 5-point Likerts scale with 1 as the lowest score (least influence) and 5 as the highest score (highest influence), according to Table 1 of encoding variables. The authors collected data by surveying 130 enterprises that are representatives for business lines in Nam Dinh province (table 2) with 4 questionnaires for each enterprise (1 director and 3 managers). There are 4 research groups that carry out direct surveys at enterprises. The survey was done in nearly 2 months, from the middle of August, 2020 to December, 2020. The total eligible responses were 520, satisfying the requirement for the quantitative data analysis. The verification of the research model and hypothesis was done through collected data and combined with the use of SPSS26 software. Estimation results of the research model are carried out in the following steps: Reliability testing, exploratory factor analysis (EFA), total variance, Pearson correlation, and regression model analysis.

TABLE I

TABLE of Variables in the Model

\begin{tabular}{|c|c|c|c|c|}
\hline Symbol & Factor name & Encoding & Criteria & Source \\
\hline \multirow[t]{6}{*}{ VON } & \multirow[t]{6}{*}{$\begin{array}{l}\text { Capital } \\
\text { accessibility } \\
\text { and usage }\end{array}$} & VON1 & $\begin{array}{l}\text { Accessibility to capital } \\
\text { markets (stock market, } \\
\text { financial leasing, etc.) }\end{array}$ & \multirow[t]{6}{*}{ [16] } \\
\hline & & VON2 & $\begin{array}{l}\text { Accessibility to capital } \\
\text { from banks/credit } \\
\text { institutions }\end{array}$ & \\
\hline & & VON3 & $\begin{array}{l}\text { Accessibility to capital } \\
\text { from other individuals } \\
\text { and organizations }\end{array}$ & \\
\hline & & VON4 & $\begin{array}{l}\text { Ability to meet loan } \\
\text { conditions (loan } \\
\text { records, collateral, } \\
\text { business plans ...) }\end{array}$ & \\
\hline & & VON5 & $\begin{array}{l}\text { Interest rate policy of } \\
\text { credit institutions }\end{array}$ & \\
\hline & & VON6 & $\begin{array}{l}\text { Ability to effectively } \\
\text { use capital in business }\end{array}$ & \\
\hline \multirow[t]{5}{*}{ SDNL } & \multirow[t]{5}{*}{$\begin{array}{l}\text { Use of } \\
\text { resource }\end{array}$} & SDNL1 & $\begin{array}{l}\text { Facilities/equipment of } \\
\text { the enterprise are } \\
\text { secured/operated well. }\end{array}$ & \multirow{5}{*}{$\begin{array}{l}\text { Considering } \\
\text { the effective } \\
\text { use of hu- } \\
\text { man re- } \\
\text { sources and } \\
\text { technology } \\
\text { in using re- } \\
\text { sources [25] } \\
{[26]}\end{array}$} \\
\hline & & SDNL2 & $\begin{array}{l}\text { The enterprise applies } \\
\text { advanced and modern } \\
\text { technology. }\end{array}$ & \\
\hline & & SDNL3 & $\begin{array}{l}\text { The enterprise invests } \\
\text { in training and human } \\
\text { resource development } \\
\text { programs. }\end{array}$ & \\
\hline & & SDNL4 & $\begin{array}{l}\text { The enterprise } \\
\text { evaluates employees } \\
\text { according to their } \\
\text { capacity and work } \\
\text { results }\end{array}$ & \\
\hline & & SDNL5 & $\begin{array}{l}\text { The result of } \\
\text { ranking/assessing the } \\
\text { completion of tasks for } \\
\text { each employee is at a } \\
\text { high level }\end{array}$ & \\
\hline DHTT & $\begin{array}{l}\text { Market } \\
\text { orientation }\end{array}$ & DHTT1 & $\begin{array}{l}\text { The enterprise's } \\
\text { business goal is derived } \\
\text { from customer } \\
\text { satisfaction. }\end{array}$ & $\begin{array}{l}\text { According } \\
\text { to [27], } \\
\text { market } \\
\text { orientation is }\end{array}$ \\
\hline
\end{tabular}

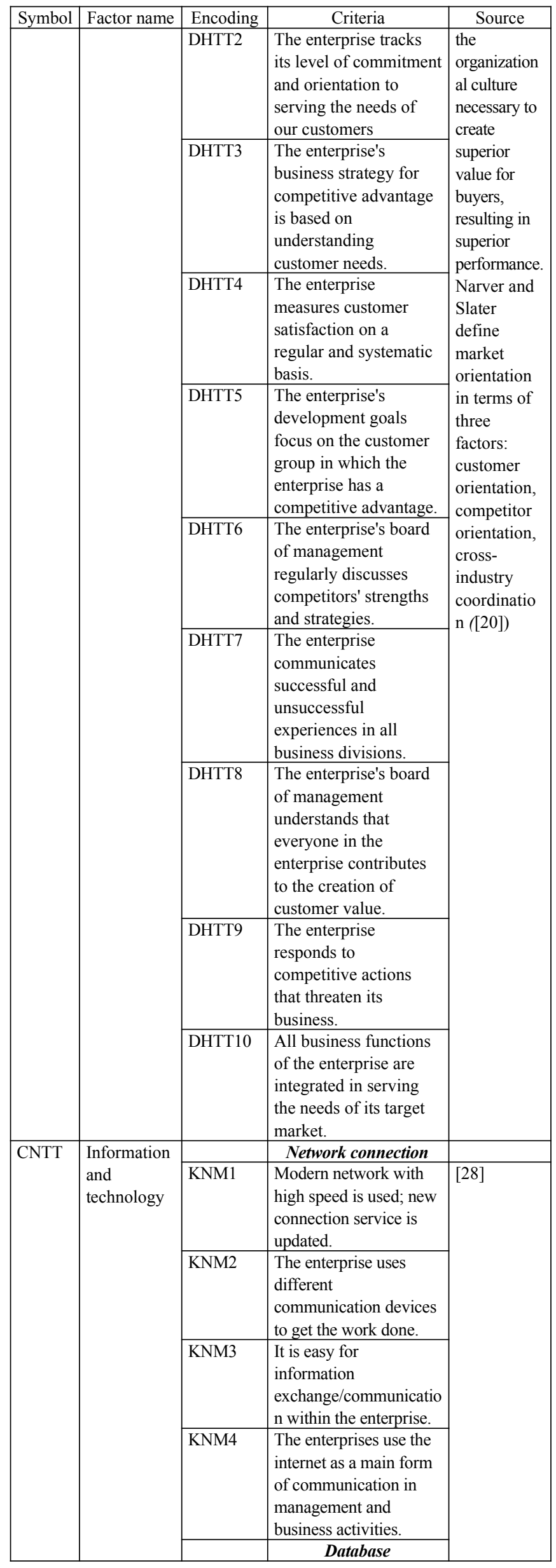




\begin{tabular}{|c|c|c|c|c|}
\hline Symbol & \begin{tabular}{|l|} 
Factor name \\
\end{tabular} & Encoding & Criteria & Source \\
\hline & & CSDL1 & $\begin{array}{l}\text { The enterprise's } \\
\text { database is stored and } \\
\text { protected. }\end{array}$ & \\
\hline & & CSDL2 & $\begin{array}{l}\text { The required data can } \\
\text { be retrieved from the } \\
\text { database at any time. }\end{array}$ & \\
\hline & & CSDL3 & $\begin{array}{l}\text { It is convenient to link } \\
\text { the databases with each } \\
\text { other and with other } \\
\text { management } \\
\text { tools/software on the } \\
\text { computer. }\end{array}$ & \\
\hline & & CSDL4 & $\begin{array}{l}\text { The common database } \\
\text { allows the ability to } \\
\text { extract reports of } \\
\text { enterprises and to } \\
\text { classify for quick usage } \\
\text { requirement. }\end{array}$ & \\
\hline \multirow[t]{5}{*}{ CSNN } & \multirow[t]{5}{*}{$\begin{array}{l}\text { Government } \\
\text { 's policies }\end{array}$} & CSNN1 & $\begin{array}{l}\text { The government's } \\
\text { system of legal } \\
\text { documents }\end{array}$ & \multirow{5}{*}{$\begin{array}{l}\text { Application } \\
\text { point of } \\
\text { view } \\
{[24],[17]} \\
{[16]}\end{array}$} \\
\hline & & CSNN2 & $\begin{array}{l}\text { The government's } \\
\text { support policies }\end{array}$ & \\
\hline & & CSNN3 & $\begin{array}{l}\text { The government's tax } \\
\text { policies }\end{array}$ & \\
\hline & & CSNN4 & $\begin{array}{l}\text { The government's } \\
\text { investment promotion } \\
\text { policies }\end{array}$ & \\
\hline & & CSNN5 & $\begin{array}{l}\text { Policies to support } \\
\text { international } \\
\text { integration }\end{array}$ & \\
\hline \multirow[t]{6}{*}{ CSDP } & \multirow{6}{*}{$\begin{array}{l}\text { Local } \\
\text { policies }\end{array}$} & CSDP1 & Local support policies & \multirow{6}{*}{$\begin{array}{l}{[24],[29]} \\
{[16]}\end{array}$} \\
\hline & & CSDP2 & Administrative reform & \\
\hline & & CSDP3 & Infrastructure & \\
\hline & & CSDP4 & $\begin{array}{l}\text { Support for land lease } \\
\text { processes }\end{array}$ & \\
\hline & & CSDP5 & $\begin{array}{l}\text { Support from business } \\
\text { associations }\end{array}$ & \\
\hline & & CSDP6 & $\begin{array}{l}\text { Policy to attract } \\
\text { investment in the high- } \\
\text { tech sector }\end{array}$ & \\
\hline \multirow[t]{8}{*}{$\mathrm{KH}$} & \multirow[t]{8}{*}{ Customers } & KH1 & $\begin{array}{l}\text { Ability to meet } \\
\text { customer requirements }\end{array}$ & \multirow{8}{*}{$\begin{array}{l}{[30],[31]} \\
{[32],[33],} \\
{[34]}\end{array}$} \\
\hline & & KH2 & $\begin{array}{l}\text { Consumption market } \\
\text { share }\end{array}$ & \\
\hline & & KH3 & $\begin{array}{l}\text { Rate of complaints } \\
\text { resolved }\end{array}$ & \\
\hline & & KH4 & Customer retention & \\
\hline & & KH5 & Rate of new customers & \\
\hline & & KH6 & $\begin{array}{l}\text { Competitive relative } \\
\text { price }\end{array}$ & \\
\hline & & KH7 & $\begin{array}{l}\text { Image, brand and } \\
\text { reputation of the } \\
\text { enterprise }\end{array}$ & \\
\hline & & KH8 & Number of ads made & \\
\hline \multirow[t]{7}{*}{ QTNB } & \multirow[t]{7}{*}{$\begin{array}{l}\text { Internal } \\
\text { processes }\end{array}$} & QTNB1 & $\begin{array}{l}\text { Rate of goods delivered } \\
\text { on time }\end{array}$ & \multirow{7}{*}{$\begin{array}{l}{[34],[33]} \\
{[32],[35],} \\
{[30]}\end{array}$} \\
\hline & & QTNB2 & $\begin{array}{l}\text { Percentage of qualified } \\
\text { goods }\end{array}$ & \\
\hline & & QTNB3 & Inventory turnover & \\
\hline & & QTNB4 & Machine operating time & \\
\hline & & QTNB5 & Employee satisfaction & \\
\hline & & QTNB6 & $\begin{array}{l}\text { Labor productivity } \\
\text { growth rate }\end{array}$ & \\
\hline & & QTNB7 & Cost saving rate & \\
\hline \multirow[t]{2}{*}{ DTPT } & \multirow{2}{*}{$\begin{array}{l}\text { Training } \\
\text { and } \\
\text { developmen } \\
\mathrm{t}\end{array}$} & DTPT1 & $\begin{array}{l}\text { Employee involvement } \\
\text { in professional } \\
\text { associations }\end{array}$ & \multirow[t]{2}{*}{$\begin{array}{l}{[30],[34]} \\
{[32],[35],} \\
{[31]}\end{array}$} \\
\hline & & DTPT2 & $\begin{array}{l}\text { Percentage of highly } \\
\text { qualified employees }\end{array}$ & \\
\hline
\end{tabular}

\begin{tabular}{|c|c|c|c|c|}
\hline Symbol & Factor name & Encoding & Criteria & Source \\
\hline & & DTPT3 & $\begin{array}{l}\text { Percentage of } \\
\text { employees } \\
\text { participating in } \\
\text { initiatives for the } \\
\text { enterprise }\end{array}$ & \\
\hline & & DTPT4 & $\begin{array}{l}\text { Quality of working } \\
\text { environment }\end{array}$ & \\
\hline & & DTPT5 & $\begin{array}{l}\text { The ability to } \\
\text { exchange information } \\
\text { within the enterprise }\end{array}$ & \\
\hline & & DTPT6 & $\begin{array}{l}\text { Percentage of } \\
\text { employees achieving } \\
\text { goals }\end{array}$ & \\
\hline & & DTPT7 & Number of staff trained & \\
\hline & & DTPT8 & $\begin{array}{l}\text { Rate of seminars, } \\
\text { exchange of } \\
\text { experiences }\end{array}$ & \\
\hline & & DTPT9 & $\begin{array}{l}\text { Leadership } \\
\text { development }\end{array}$ & \\
\hline
\end{tabular}

TABLE 2

Survey Sample Classified by Business Sectors

\begin{tabular}{|c|l|c|c|c|c|}
\hline \multirow{2}{*}{ No } & \multirow{2}{*}{$\begin{array}{l}\text { Business } \\
\text { sector }\end{array}$} & \multicolumn{2}{|c|}{$\begin{array}{l}\text { Number of } \\
\text { enterprises }\end{array}$} & \multicolumn{2}{|c|}{$\begin{array}{c}\text { Number of sureyed } \\
\text { enterprises }\end{array}$} \\
\cline { 3 - 6 } & $\begin{array}{c}\text { Quantit } \\
\mathrm{y}\end{array}$ & $\%$ & Quantity & $\%$ \\
\hline 1 & $\begin{array}{l}\text { Industry and } \\
\text { construction }\end{array}$ & 2597 & 42,8 & 68 & 52,3 \\
\hline 2 & $\begin{array}{l}\text { Trade and } \\
\text { services }\end{array}$ & 3041 & 50,2 & 47 & 36,2 \\
\hline 3 & $\begin{array}{l}\text { Agriculture, } \\
\text { forestry and } \\
\text { fisheries }\end{array}$ & 423 & 7,0 & 15 & 11,5 \\
\hline & \multicolumn{1}{|c|}{ Total } & 6061 & 100 & 130 & 100 \\
\hline
\end{tabular}

\section{Results}

\section{A. Analysis of the scale's reliability}

The authors tested the reliability of the data through the Cronbach's Alpha coefficient. The scale only ensures reliability when Cronbach's Alpha coefficient is greater than 0.6, the scale has good reliability when varying in the range from 0.7 to 0.8 . If the scale is greater than or equal to 0.6 , then the scale is acceptable. In terms of reliability and correlation coefficient, the total variable is greater than 0.3. During the test, the authors removed the variable Capital 4 because the correlation coefficient of the total variable was less than 0.3 . The results of the scale test are presented in Table 3.

TABLE 3

RESUltS OF SCALE ANALYSIS

\begin{tabular}{|c|l|c|}
\hline $\begin{array}{c}\text { N } \\
\mathbf{o}\end{array}$ & \multicolumn{1}{|c|}{ Scale } & $\begin{array}{c}\text { Cronbach's } \\
\text { Alpha }\end{array}$ \\
\hline 1 & Capital accessibility (VON) & 0,856 \\
\hline 2 & Use of resource (SDNL) & 0,843 \\
\hline 3 & Market orientation (DHTT) & 0,884 \\
\hline 4 & Network connection & 0,832 \\
\hline 5 & Database & 0,834 \\
\hline 6 & Government's policies (CSNN) & 0,831 \\
\hline 7 & Local policies (CSDP) & 0,844 \\
\hline 8 & $\begin{array}{l}\text { Business performance with non-financial } \\
\text { measure (Customer) (KH) }\end{array}$ & 0,887 \\
\hline 9 & $\begin{array}{l}\text { Business performance with non-financial } \\
\text { measure (internal processes) (QTNB) }\end{array}$ & 0,886 \\
\hline 10 & $\begin{array}{l}\text { Business performance in non-financial } \\
\text { measure (training and development) (DTPT) }\end{array}$ & 0,881 \\
\hline
\end{tabular}

Source: Analytical results from survey data, SPSS 26 software 
Thus, all variables satisfy the conditions in the reliability analysis of the scale through Cronbach's Alpha coefficient.

\section{B. Exploratory factor analysis}

The results of EFA analysis of the dependent variables for business performance according to non-financial measures are: Customers, Internal processes, Training and development. Results of KMO and Bartlett's test of are in Table 4. Results of EFA analysis of dependent variables are shown in Table 5.

TABLE 4

Results of KMO and Bartlett's Test of IndePendent Variables

\begin{tabular}{|l|c|c|c|}
\hline \multicolumn{1}{|c|}{ Criteria } & $\begin{array}{c}\text { Results } \\
\text { (KH) }\end{array}$ & $\begin{array}{c}\text { Result } \\
\text { (QTNB) }\end{array}$ & $\begin{array}{c}\text { Result } \\
\text { (DTPT) }\end{array}$ \\
\hline KMO index & 0,928 & 0,921 & 0,926 \\
\hline Bartlett's test with sig value & 0,000 & 0,000 & 0,000 \\
\hline Total value of variance extracted & 56,029 & 59,449 & 51,409 \\
\hline Minimum Eigenvalue & 4,482 & 4,161 & 4,627 \\
\hline
\end{tabular}

Source: Analytical results from survey data, SPSS 26 software

$$
\text { TABLE } 5
$$

Results of KMO and Bartlett's Test of Dependent Variables

\begin{tabular}{|l|c|}
\hline \multicolumn{1}{|c|}{ Criteria } & Results (KH) \\
\hline KMO index & 0,914 \\
\hline Bartlett's test with sig value & 0,000 \\
\hline Total value of variance extracted & 61,544 \\
\hline Minimum Eigenvalue & 1,575 \\
\hline
\end{tabular}

Source: Analytical results from survey data, SPSS 26 software

Results of dependent variable analysis for KMO index satisfy the condition $>0.5$, so the EFAs is appropriate with the actual data. The Bartlett test with sig value $<0.05$ means that the observed variables are linearly correlated with the representative factor. The results of running the observed variables all with factor loadings greater than 0.5 obtained a rotation factor matrix table of independent variables with 6 factors extracted and rearranged as shown in Table 6 and rotation matrix of the dependent variables (table 7).

TABLE 6

Rotation FACTOR MATRIX RESUltS OF INDEPENDENT VARIABLES

\begin{tabular}{|c|c|c|c|c|c|c|}
\hline & \multicolumn{6}{|c|}{ Component } \\
\hline & 1 & 2 & 3 & 4 & 5 & 6 \\
\hline CSDL3 & .781 & & & & & \\
\hline CSDL1 & .760 & & & & & \\
\hline KNM4 & .759 & & & & & \\
\hline CSDL4 & .756 & & & & & \\
\hline KNM1 & .738 & & & & & \\
\hline KNM3 & .735 & & & & & \\
\hline KNM2 & .723 & & & & & \\
\hline DHTT7 & & .799 & & & & \\
\hline DHTT5 & & .760 & & & & \\
\hline DHTT6 & & .758 & & & & \\
\hline DHTT3 & & .746 & & & & \\
\hline DHTT1 & & .712 & & & & \\
\hline DHTT8 & & .710 & & & & \\
\hline CSDP5 & & & .739 & & & \\
\hline CSDP6 & & & .729 & & & \\
\hline CSDP1 & & & .728 & & & \\
\hline CSDP2 & & & .710 & & & \\
\hline CSDP3 & & & .707 & & & \\
\hline
\end{tabular}

\begin{tabular}{|c|c|c|c|c|c|c|}
\hline & \multicolumn{6}{|c|}{ Component } \\
\hline & 1 & 2 & 3 & 4 & 5 & 6 \\
\hline CSDP4 & & & .656 & & & \\
\hline VON6 & & & & .793 & & \\
\hline VON2 & & & & .790 & & \\
\hline VON4 & & & & .787 & & \\
\hline VON1 & & & & .767 & & \\
\hline VON5 & & & & .759 & & \\
\hline SDNL2 & & & & & .810 & \\
\hline SDNL4 & & & & & .784 & \\
\hline SDNL5 & & & & & .775 & \\
\hline SDNL1 & & & & & .747 & \\
\hline SDNL3 & & & & & .710 & \\
\hline CSNN5 & & & & & & .790 \\
\hline CSNN1 & & & & & & .738 \\
\hline CSNN3 & & & & & & .734 \\
\hline CSNN2 & & & & & & .707 \\
\hline CSNN4 & & & & & & .698 \\
\hline
\end{tabular}

TABLE 7

Roration Factor Matrix Results of Dependent Variables

\begin{tabular}{|c|c|c|c|c|c|}
\hline \multirow{2}{*}{ Customer } & Factor & Internal & Factor & Training and & Factor \\
\cline { 6 - 6 } & $\mathbf{1}$ & processes & $\mathbf{1}$ & development & $\mathbf{1}$ \\
\hline KH2 & .784 & QTNB7 & .792 & DTPT2 & .760 \\
\hline KH5 & .783 & QTNB2 & .787 & DTPT6 & .745 \\
\hline KH8 & .779 & QTNB6 & .785 & DTPT3 & .738 \\
\hline KH1 & .761 & QTNB3 & .769 & DTPT8 & .722 \\
\hline KH6 & .749 & QTNB1 & .768 & DTPT1 & .722 \\
\hline KH4 & .724 & QTNB4 & .748 & DTPT4 & .712 \\
\hline KH3 & .717 & QTNB5 & .746 & DTPT7 & .689 \\
\hline KH7 & .686 & & & DTPT5 & .684 \\
\hline \multicolumn{7}{|l|}{ Source: Analytical results from survey data, SPSS 26 software }
\end{tabular}

\section{Regression correlation results}

In this study, the authors want to test the regression correlation with business performance according to non-financial measures including 3 indicators: customer, internal processes, and training and development. The authors hope to identify which factors affect business performance of enterprises in Nam Dinh on all three criteria so that enterprises need to focus on solutions to improve their business performance. In Table 8, we see the existence of a relationship correlation between business between the dependent variable business performance measured by non-financial measures with independent variables (local policies, information technology, the government's policies, market orientation, capital accessibility and usage, use of resource) at a significance level of $1 \%$ (ie, there is a linear correlation at the $99 \%$ confidence level). Thus, independent variables can be included in the model to explain business performance (measured by non-financial measures). In addition, the correlation coefficient between the independent variables also exists as low as 0.121 to as high as 0.650 , so there is no concern about multicollinearity between the independent variables in the regression analysis. 
TABLE 8

MATRIX OF CORRELATION COEFFICIENTS BETWEEN VARIABLES AND THE NON-FINANCIAL DEPENDENT VARIABLE "CUSTOMER"

\begin{tabular}{|c|c|c|c|c|c|c|c|c|}
\hline & & PTC & CSDP & CNTT & CSNN & DHTT & VON & SDNL \\
\hline PTC & $\begin{array}{l}\text { Pearson } \\
\text { Correlation }\end{array}$ & 1 & $.510^{* * *}$ & $.629^{* * *}$ & $.399^{* * *}$ & $.650^{* *}$ & $.326^{* *}$ & $.634^{* * *}$ \\
\hline $\begin{array}{l}\mathrm{CSD} \\
\mathrm{P}\end{array}$ & $\begin{array}{l}\text { Pearson } \\
\text { Correlation }\end{array}$ & $.510^{* * *}$ & 1 & $.238^{* * *}$ & $.510^{* * *}$ & $.267^{* *}$ & $.344^{* * *}$ & $.165^{* *}$ \\
\hline \begin{tabular}{|l|}
$\mathrm{CNT}$ \\
$\mathrm{T}$
\end{tabular} & $\begin{array}{l}\text { Pearson } \\
\text { Correlation }\end{array}$ & $.629^{* * *}$ & $.238^{* * *}$ & 1 & $.203^{* * *}$ & $.486^{* * *}$ & $.136^{* *}$ & $.319^{* * *}$ \\
\hline $\begin{array}{l}\mathrm{CSN} \\
\mathrm{N} \\
\end{array}$ & $\begin{array}{l}\text { Pearson } \\
\text { Correlation }\end{array}$ & $.399^{* * *}$ & $.510^{* * *}$ & $.203^{* * *}$ & 1 & $.208^{* * *}$ & $.284^{* * *}$ & $.136^{* *}$ \\
\hline \begin{tabular}{|c} 
DHT \\
T
\end{tabular} & $\begin{array}{l}\text { Pearson } \\
\text { Correlation }\end{array}$ & $.650^{* * *}$ & $.267^{* * *}$ & $.486^{* *}$ & $.208^{* *}$ & 1 & $.121^{* *}$ & $.277^{* * *}$ \\
\hline VON & $\begin{array}{l}\text { Pearson } \\
\text { Correlation }\end{array}$ & $.326^{* *}$ & $.344^{* * *}$ & $.136^{* *}$ & $.284^{* * *}$ & $.121^{* * *}$ & 1 & $.121^{* * *}$ \\
\hline $\begin{array}{l}\text { SDN } \\
\text { L }\end{array}$ & $\begin{array}{l}\text { Pearson } \\
\text { Correlation }\end{array}$ & $.634^{* *}$ & $.165^{* * *}$ & $.319^{* * *}$ & $.136^{* * *}$ & $.277^{* * *}$ & $.121^{* *}$ & 1 \\
\hline
\end{tabular}

Looking at Table 6 , the model shows that the adjusted Rsquared coefficient is 0.805 , meaning the independent variables affect $80.5 \%$ of the change of the dependent variable. The remaining $19.5 \%$ is the effect of factors other than the model and random error. The Durbin-Watson coefficient $=$ 1.903 is in the range from 1.5 to 2.5 , so there is no first order series autocorrelation. The ANOVA results has sig $=$ $0.000<0.05$, so the regression model fits the data set and can be used. With the regression results, there is no multicollinearity phenomenon, the VIP coefficients of the independent variables are less than 2 . The results are statistically significant and accepted with sig $<0.05$, the coefficient B of the independent variables. All the variables have a positive sign, which means that they have a positive effect (in the same direction) with the dependent variable, the hypotheses are accepted.

Based on the standardized regression coefficient beta with independent variables having coefficient sig $<0.05$, it is seen that the factor of use of resources has the strongest influence on business performance (measured by non-financial criteria) with the coefficient of 0.401 . The order of influence of the following variables is market orientation (0.325), information technology (0.261), local policies $(0.216)$, accessibility and use of capital (0.104), the government's policies (0.085).

Based on the unnormalized regression coefficient B with independent variables having sig coefficient $<0.05$, in the condition that other variables do not change the value, when the variable of local policy increases by 1 point, the business performance (measured by non-financial indicators) increases by 0.139 points; the variable of information technology increases by 1 point, business performance (measured by non-financial criteria) increases by 0.167 points; the variable of government's policy increases by 1 point, business performance (measured by non-financial criteria) increases by 0.053 points; the variable of market orientation increased by 1 point, business performance (measured by non-financial criteria) increases by 0.199 points; the variable of capital accessibility and usage increases by 1 point, the business performance (measured by non-financial criteria) increases by 0.063 points; the variable of use of resource using resources increased by 1 point, business performance (measured by non-financial criteria) increases by 0.255 points.
Table 9 Results of Multivariable Regression With Business Performance From Non-Financial Aspects as the Dependent Variable

\begin{tabular}{|c|c|c|c|c|c|c|c|}
\hline \multirow[t]{2}{*}{ Model } & \multicolumn{2}{|c|}{$\begin{array}{l}\text { Unnormalized } \\
\text { regression co- } \\
\text { efficients }\end{array}$} & \multirow{2}{*}{\begin{tabular}{|l}
$\begin{array}{c}\text { Normal- } \\
\text { ized re- } \\
\text { gression } \\
\text { coeffi- } \\
\text { cient }\end{array}$ \\
Beta \\
\end{tabular}} & \multirow{2}{*}{$\mathrm{T}$} & \multirow{2}{*}{$\begin{array}{l}\text { Sig } \\
\text { level }\end{array}$} & \multicolumn{2}{|c|}{$\begin{array}{l}\text { Multicollinearity } \\
\text { test }\end{array}$} \\
\hline & B & \begin{tabular}{|l} 
Stan- \\
dard er- \\
ror
\end{tabular} & & & & \begin{tabular}{|l|} 
Accept- \\
ability
\end{tabular} & VIF \\
\hline (Constant) & .968 & .062 & & 15.643 & .000 & & \\
\hline \begin{tabular}{|l|} 
CSDP \\
\end{tabular} & .139 & .015 & .216 & 9.124 & .000 & .670 & 1.493 \\
\hline CNTT & .167 & .015 & .261 & 11.370 & .000 & .715 & 1.399 \\
\hline CSNN & .053 & .014 & .085 & 3.708 & .000 & .719 & 1.391 \\
\hline DHTT & .199 & .014 & .325 & 14.257 & .000 & .725 & 1.380 \\
\hline VON & .063 & .013 & .104 & 4.990 & .000 & .861 & 1.161 \\
\hline \begin{tabular}{|l} 
SDNL \\
\end{tabular} & .255 & .013 & .401 & 19.286 & .000 & .871 & 1.148 \\
\hline \multicolumn{5}{|l|}{$\mathrm{R}^{2}$} & \multicolumn{3}{|r|}{.807} \\
\hline \multicolumn{5}{|l|}{ Adjusted $\mathrm{R}^{2}$} & \multirow{2}{*}{\multicolumn{3}{|c|}{$\begin{array}{r}.805 \\
0,000\end{array}$}} \\
\hline \multicolumn{5}{|c|}{ Sig. F Change } & & & \\
\hline \multicolumn{5}{|c|}{ Durbin-Watson } & \multicolumn{3}{|r|}{1.903} \\
\hline
\end{tabular}

The regression model suitable with the $5 \%$ significance level is as follows:

YHQHDKD $($ PTC $)=0,968+0,139$ CSĐP $+0,167 \mathrm{C}$ NTT $+0,053$ CSNN $+0,199$ DHTT $+0,063 \mathrm{VON}+0,255$ $\mathrm{SDNL}+\varepsilon$

In which:

YHQHDKD (PTC): Business performance measured by non-financial criteria (including customers, internal processes and development training)

CSDP: Local policies

CNTT: Information and technology

CSNN: The government's policies

DHTT: Market orientation

VON: Capital accessibility and usage

SDNL: Use of resource

\section{Discussion}

This study on factors affecting business performance from non-financial aspects at enterprises in Nam Dinh province has focused on studying the factors affecting business performance of enterprises to help them and organizations have a better view of their business activities and to find solutions to improve their business performance. By quantitative research method in the regression model, the study has estimated and identified factors affecting business performance in terms of non-financial aspects. There are 6 influencing factors and the level of influence of each factor in order is as follows: (1) Use of resource (2) Market orientation, (3) Information technology, (4) Local policies, (5) Capital accessibility and use, (6) Government's policies. They are statistically significant in the model. The variables are statistically significant at $5 \%$; all have a positive correlation with business performance and also agree with viewpoints in previous studies, that is, the better the use of resources, the higher the business performance will be, according to [26], [36], [37], [38], [39]. According to the survey results, the use of resources in terms of technology and human resources of enterprises in Nam Dinh is still limited. Regard- 
ing market orientation in striving to meet the needs of current and potential customers, enterprises will focus on strategies that are considered reliable in order to improve customers' awareness of quality of products and services, thereby enabling them to create and maintain better customer value. This is in line with results of [27], [40], [41]. The survey results show that market orientation based on products with strengths and competitive advantages has not been carried out effectively. Regarding IT, [42] suggests that IT is related to increased productivity. According to [42], technological competence is positively and significantly related to business performance. Another study by [43] shows that technology competence affects the overall success of an enterprise. According to the survey results, the database at enterprises is stored and exploited ineffectively. Regarding local policies, according to [16], [29], IT has a positive influence on business performance. Currently, according to enterprises, the province's policy, procedures and infrastructure have many limitations that need to be overcome. Regarding capital accessibility and use of capital [44] believe that effective use of business capital with a properly allocated capital structure will help enterprises. According to [45], as the main source of capital for enterprises, the system of financial and credit institutions will have a large influence on the size of the capital market and the growth rate of enterprises. [16] also suggests that capital accessibility affects business performance. Specifically, if accessibility to capital in capital markets and credit institutions is good, policies on loan procedures are simple and convenient, interest rate policies are reasonable, the business performance of enterprises will be higher. Survey results show that enterprises have difficulties in accessing capital sources in the province. Regarding state policies, the studies by [10], [30], [11] state that the number of forms of state support that enterprises have ever received has a positive effect on business performance. The government creates supportive policies for the development of enterprises. Enterprises are the driving force of socio-economic development, while finance is an important lifeline, leading businesses and the economy to develop. In fact, the government's policies to encourage investment and support for international integration have not been effective.

\section{Conclusions and Recommendations}

In order to improve the business performance of enterprises in Nam Dinh province, the authors propose a number of solutions from the research results as follows:

Firstly, the use of resource has the strongest influence on the business performance of enterprises. Enterprises believe that it is necessary to focus on the human resource factor because human is the decisive factor for all activities of enterprises. Nam Dinh province needs to focus on training highquality human resources, on practice and close association with training institutions. It is necessary to have in-depth training policies to improve workers' skills and develop professional demeanor. Enterprises need to have specific job descriptions and clear salary regulations clearly according to employees' ability to contribute at work. In addition, technology resources, if used and exploited well, will help businesses improve their business operations better. Nam Dinh enterprises need to carry out in-depth investment to upgrade existing factories and conduct planning and new investments to meet the requirements of origin of goods. Attention should be given to building a technical and design team. Enterprises should actively invest in renewing technology lines, applying quality management methods according to international standards, productivity improvement tools such as: ISO 9001; 5S, TPM, Lean... Also, they should apply advanced, highly automated, closed production models and IT for control on smart screens, helping workers control machines in a convenient, accurate manner to save time, labour force, and manpower.

Secondly, in terms of market orientation, in order to effectively target customers, businesses should recognize the needs of customers better than their competitors. If they can do so and then be able to fulfill such needs, they will certainly gain more market share and higher profits. To implement customer orientation more effectively, employees in the enterprise should be encouraged to develop customer focus, access to customizations, and use information to provide better service quality of service. The better service quality, the better the business performance. Enterprises in Nam Dinh province should aim to target customer markets with the province's strengths in textiles, apparel, footwear, mechanics. They should monitor the level of commitment and customer orientation and measure customer satisfaction on a regular and systematic basis.

Thirdly, the fourth industrial revolution (Industry 4.0) is formed from the strong development of digital technologies. IT is the link that plays a very important role in this revolution. According to the survey results, the storage and exploitation of databases at enterprises for business purposes is still limited. Therefore, businesses need to use the data storage in many different forms such as: (1) On-site storage: This is the original data storage method. An on-site data solution that often involves the server is owned and managed by the enterprise itself; (2) Colocation: While many enterprises still want to store their valuable data on devices they own and control, they don't want to have to deal with the problems that arise with managing those devices themselves; (3) Public Cloud: Small and medium-sized companies cannot afford to invest in expensive hardware to store data. Transferring all data to a public cloud provider helps enterprises become more flexible; (4) Private Cloud: The open nature of a public cloud environment makes it difficult to protect sensitive data from unauthorized access. For companies that don't want to take these risks, private clouds deployed through a virtualized data center provide a much higher level of security, especially when combined with cryptographic protocols.

Fourthly, on local policies, it is necesary to continue to promote reform of administrative procedures in the field of business registration and investment registration. Regularly review administrative procedures in accordance with the provisions of law, abolish unnecessary procedures. Ensure publicity and transparency of all administrative procedures. Promote computerization at the one-stop shop in the process of handling administrative procedures of functional state management agencies. Equip material and technical foundations to modernize public administration. Strengthen coordi- 
nation between departments, branches, People's Committees of districts and cities in solving legal problems arising in the process of establishment, investment and operation of enterprises. Improve the quality of human resources to implement state administrative reform. Strengthen the review, inspection and supervision of implementation of administrative procedures. Improve organizational capacity. Promote streamlined administrative procedures associated with the application of IT in the operations of State agencies. Regarding infrastructure in Nam Dinh province, it is necessary to: improve the quality of regional planning combined with sectoral development planning in the province; ensure publicity and transparency of plans, processes and procedures for land access; study and issue preferential regulations to encourage construction enterprises to invest in building infrastructure of industrial parks and industrial clusters for enterprises; and integrate targeted support capital sources from the state budget.

Fifthly, about the ability to access and use capital effectively, for businesses that have just got a loan for the first time but do not have enough collateral: through the appraisal, if there is enough basis to evaluate the plan as feasible, effective and that it belongs to the strong or priztized industry and field in accordance with the development orientation of the province, banks and credit institutions make agreements with enterprises to provide information on the progress of project implementation and transfer all project revenues to a bank account for debt recovery. This content is agreed upon in the credit contract so that there is a basis for early handling of contract violations when detecting that enterprises do not comply or transfer the revenue to an account at another bank, limiting the loss of debt collection. On that basis, the bank applies the form of lending a part of the outstanding balance without collateral and only needs to monitor the implementation progress and revenue of the plan to recover the debt. For enterprises that have relationships or are taking loans at banks and credit institutions: in reviewing the loan history, if the customer has good cooperation, the bank or credit institution will re-evaluate all collaterals. If collaterals are still more valuable than the guarantee obligations, they continue to make loans when the enterprise has a feasible and effective plan, strictly supervises the implementation of the plan and the enterprise's cash flow, and apply additional collateral methods such as third-party guarantee, mortgage of future assets, receivables, inventory (if any) to collect debts.

Sixthly, for policies of the government, it is necessary to improve preferential policies on land use, infrastructure support policies, investment promotion policy and support for public services, and to develop policies to support human resource training. Regarding policies to support international integration, it is necessary to formulate policies to boost exports and limit imports of non-essential consumer goods and luxury goods, formulate policies to support and develop high-quality human resources, continue to promote the effectiveness of industrial development policies in the direction of focusing on attracting multinational corporations.

\section{REFERENCES}

[1] Kap1an, R. S., \& Norton, D. (1992). The balanced scorecard-measure that drive performance. Harvard Business Review, 71-79.

[2] Cross, K. F., \& Lynch, R. L. (1988). The "SMART" way to define and sustain success. National productivity review, 8(1), 23-33.

[3] Keegan, D. P., Eiler, R. G., \& Jones, C. R. (1989). Are your performance measures obsolete? Strategic Finance, 70(12), 45.

[4] Neely, A., Mills, J., Gregory, M., Richards, H., Platts, K., \& Bourne, M. (1996). Getting the measure of your business, University of Cambridge. Manufacturing Engineering Group, Mill Lane, Cambridge.

[5] Turney, P. B., \& Anderson, B. (1989). Accounting for continuous improvement. MIT Sloan Management Review, 30(2), 37.

[6] Kokko, A., \& Sjöholm, F. (2005). The internationalization of Vietnamese small and medium-sized enterprises. Asian Economic Papers, 4(1), 152-177.

[7] Hang, V. T. T. (2015). A study of factors affecting business performance of construction companies listed on the Vietnam stock exchange (Master thesis), University of Danang.

[8] Panco, R., \& Korn, H. (1999). Understanding factors of organizational mortality: considering alternatives to firm failure. From http:// www.eaom.org.

[9] Hansen, H., Rand, J., \& Tarp, F. (2018). SME growth and survival in Vietnam: Did direct government support matter? Institute of Economics Discussion Paper No. 04-13, Copenhagen: University of Copenhagen. In.

[10] Nghi, N. Q., \& Nam, M. V. (2011). "Factors affecting business efficiency of small and medium enterprises in Can Tho city". Can Tho University Journal of Science No. 19b.

[11] Trong, T. D. L. v. N. D. (2010). " Production and business efficiency of small and medium-sized enterprises in the Mekong Delta",. anking Technology Review, 50(1).

[12] Tan, N. M., Danh, V. T., \& Ngan, T. T. (2015). Factors affecting the efficiency of production and business activities of small and medium sized enterprises in Bac Lieu province. Can Tho University Journal of Science, 38, 34-40.

[13] Zeitun, R., \& Tian, G. G. (2014). Capital structure and corporate performance: evidence from Jordan. Australasian Accounting Business \& Finance Journal, Forthcoming.

[14] Ndoro, G. (2012). Executive compensation and firm performance: evidence from the UK charities. University of Nottingham,

[15] Hang, T. T. (2019). A study of factors affecting business performance of SMEs in Hanoi city. (Research topic), Hanoi University of Industry.

[16] Lý, P. T. M. (2011). Analyzing the impact of factors affecting the business activities of small and medium enterprises in Thua Thien Hue. Journal of Science and Technology vol 2 (43).

[17] Danh, V. T., Cuong, O. Q., \& Quang, T. B. (2013). Analysis of factors affecting the development of small and medium-sized enterprise economy in Hau Giang province. Scientific journal of Can Tho University, vol 27, page 34-44.

[18] Barney, J. (1991). Firm resources and sustained competitive advantage. Journal of management, 17(1), 99-120.

[19] Chi, C. G., \& Gursoy, D. (2009). Employee satisfaction, customer satisfaction, and financial performance: An empirical examination. International Journal of Hospitality Management, 28(2), 245-253.

[20] Bagheri, M. M., Hamid, A., Rezaei, A., \& Mardani, A. (2012). Relationship among information technology investment, firm performance, innovation and firm growth, case study: Largest Iranian manufacturers. International Journal of Fundamental Psychology \& Social Sciences, 2(3), 57-64.

[21] Bunei, D. K. (2013). An Evaluation Of Information Technology Investment Influence On Organizational Performance: A Case Study of Kenyan Commercial Banks. United States International UniversityAfrica,

[22] Anand, A. (2013). The effects of IT capabilities on firm performanceevidence from the healthcare industry.

[23] Ismail, A., \& Mamat, M. (2012). The relationship between information technology, process innovation and organizational performance. International Journal of Business and Social Science, 3(2).

[24] Hung, D. N. (2016). A study of factors affecting business performance of small and medium enterprises in Thai Binh province (Provincial research project), Department of Science and Technology of Thai Binh Province

[25] Fitzgerald, L., Johnston, R., Brignall, T., Silvestro, R., \& Voss, C. (1991). Performance measurement in service businesses (Vol. 69): Chartered Institute of Management Accountants London. 
[26] Wadongo, B., Odhuno, E., Kambona, O., \& Othuon, L. (2010). Key performance indicators in the Kenyan hospitality industry: a managerial perspective. Benchmarking: An international journal.

[27] Narver, J. C., \& Slater, S. F. (1990). The effect of a market orientation on business profitability. Journal of marketing, 54(4), 20-35.

[28] Aldalayeen, B. O., Moh'd Alkhatatneh, W. R. n., \& AL-Sukkar, A. S. (2013). Information technology and its impact on the financial performance: An applied study in industrial companies (mining and extraction). European Scientific Journal, 9(10).

[29] Hiep, P. M., \& Huong, V. T. B. (2019). Factors affecting the business performance of small and medium enterprises in Ben Tre city. Article in the Journal of Finance - vol 2

[30] Khan, M. H.-U.-Z., \& Halabi, A. K. (2009). Perceptions of firms learning and growth under knowledge management approach with linkage to balanced scorecard (BSC): Evidence from a multinational corporation of Bangladesh.

[31] Khan, H.-U.-Z., Halabi, A. K., \& Masud, M. Z. (2010). Empirical study of the underlying theoretical hypotheses in the balanced scorecard (bsc) model: Further evidence from Bangladesh. Asia-Pacific Management Accounting Journal, 5(2), 45-73.

[32] De Felice, F., \& Petrillo, A. (2013). Key success factors for organizational innovation in the fashion industry. International Journal of Engineering Business Management, 5(Godište 2013), 5-27.

[33] Chriyha, A., Beidouri, Z., \& Bouksour, O. (2012). Proposal of a Performance Model Based on the Balanced Scorecard for the Moroccan Textile Industry. International Journal of Computer Science Issues (IJCSI), 9(5), 410

[34] Karabay, G., \& Kurumer, G. (2012). Managing through strategic performance management in apparel companies. Fibres \& Textiles in Eastern Europe(4 (93)), 13--19.

[35] Chimwani, P., Nyamwange, O., \& Otuyo, R. (2013). Application of strategic performance measures in small and medium-sized manufacturing enterprises in Kenya: The use of the balanced scorecard perspectives. International Journal of Management Sciences and Business Research, 2(6)
[36] Wong, K. K., \& Kwan, C. (2001). An analysis of the competitive strategies of hotels and travel agents in Hong Kong and Singapore. International Journal of Contemporary Hospitality Management.

[37] Wu, L.-Y. (2007). Entrepreneurial resources, dynamic capabilities and start-up performance of Taiwan's high-tech firms. Journal of Business research, 60(5), 549-555.

[38] Galbreath, J., \& Galvin, P. (2004). Which Resources Matter? A FineGrained Test of the Resource-Based View of the Firm. Paper presented at the Academy of Management Proceedings.

[39] Tho, N. D., \& Trang, N. T. M. (2009). Dynamic competitiveness of Vietnamese enterprises in scientific research in business administration. Ha Noi: Information and Communications Publishing House, 155-238.

[40] Johnson, W., \& Huizenga, W. (2001). Market Orientation in the Asian Mobile Telecommunication Industry: Do Buyer and Seller Perceptions Concur. School of Business and Entrepreneurship, Nova Southeastern University, Fort Lauderdale-Davie, FL.

[41] Crosby, L. A., Evans, K. R., \& Cowles, D. (1990). Relationship quality in services selling: an interpersonal influence perspective. Journal of marketing, 54(3), 68-81.

[42] Hill, K. O., \& Meltz, G. (1997). Fiber Bragg grating technology fundamentals and overview. Journal of lightwave technology, 15(8), 1263-1276.

[43] García-Muiña, F. E., \& Navas-López, J. E. (2007). Explaining and measuring success in new business: The effect of technological capabilities on firm results. Technovation, 27(1-2), 30-46.

[44] Thuy, L. P., Duy, V. Q., \& Le Thong, P. (2020). The relation between business performance and capital structure of enterprises in Vietnam. Journal of Asian Business and Economic Studies, 30(6), 28-45.

[45] Phuong, N. T. M., \& Cuc, N. T. T. (2019). Evaluating the ability to access capital from credit institutions of enterprises in Nghe An province. Journal of Economic Development, 19-25. 